\title{
NILAI UNGGUL PENDIDIKAN PRASEKOLAH DALAM MEMPERSIAPKAN ANAK MEMASUKI JENJANG SEKOLAH FORMAL ( Studi di TK Al Qur'an Wahdatul Ummah Kota Metro )
}

\author{
Iswati $^{1}$, Bayu Ardiwansyah ${ }^{2}$ \\ Universitas Muhammadiyah Metro ${ }^{1}$, STKIP PGRI Metro ${ }^{2}$ \\ Iswatiummetro@yahoo.com, bayu21polos@gmail.com
}

\begin{abstract}
School readiness is an important thing that children need to have before they enter elementary school. So the purpose of this study is to answer What are the programs in the Al-Qur'an Wahdatul Ummah Kindergarten, How to prepare children for the Formal Schools and What are the excellent programs offered by the Kindergarten Al-Qur'an Wahdatul Ummah in preparing children to enter the Formal Schools. In answering these problems, this study uses a type of qualitative field research using methods, namely; interview, observation and documentation. Whereas in the data analysis technique the writer uses descriptive qualitative analysis techniques. The results of the study in general showed that the PAUD Program in Wahdatul Ummah included; Daycare, play groups, Al-Qur'an kindergarten, TPA, mother and child education (parenting). The efforts of AlQur'an Kindergarten in preparing children for formal schooling include; by preparing the child's personal, social and academic. In addition, TKIT Wahdatul Ummah also considers aspects of the teacher, material, infrastructure, methods and evaluation. The excellent program offered by TK Al-Qur'an Wahdatul Ummah in preparing children to enter the Formal School level is through memorizing good readings, prayers, short letters and introducing letter numbers, reading, writing and counting but in a fun way through games and song. Wahdatul Ummah's Al-Qur'an kindergarten programs in preparing children for formal schooling are quite effective and work well.
\end{abstract}

\section{Keyword: Superior Value, formal School.}

\begin{abstract}
Abstrak
Kesiapan sekolah merupakan hal penting yang perlu dimiliki anak sebelum ia masuk ke Sekolah Dasar (SD). Sehingga tujuan penelitian ini adalah untuk menjawab Apa saja program di TK Al-Qur'an Wahdatul Ummah, Bagaimana upaya mempersiapkan anak ke jenjang Sekolah Formal serta Apa saja program unggulan yang ditawarkan TK Al-Qur'an Wahdatul Ummah dalam mempersiapkan anak memasuki jenjang Sekolah Formal. Dalam menjawab permasalahan tersebut Penelitian ini menggunakan jenis penelitian kualitatif lapangan dengan menggunakan metode yaitu; interview, observasi dan dokumentasi. Sedangkan dalam teknik analisis data penulis menggunakan teknik analisis deskriptif kualitatif. Hasil penelitian secara umum menunjukkan bahwa
\end{abstract}


Program PAUD yang ada di Wahdatul Ummah antara lain; Tempat penitipan anak, play group, TK Al-Qur'an, TPA, pendidikan ibu dan anak (parenting). Upaya TK Al-Qur'an dalam mempersiapkan anak ke jenjang Sekolah Formal antara lain; dengan mempersiapkan personal, sosial dan akademik anak. Selain itu TKIT Wahdatul Ummah juga mempertimbangkan aspek guru, materi, sarana prasarana, metode dan evaluasi. Program unggulan yang ditawarkan TK AlQur'an Wahdatul Ummah dalam mempersiapkan anak memasuki jenjang Sekolah Formal yaitu melalui menghafal baik bacaan do, shalat, surat-surat pendek dan mengenalkan angka huruf, membaca, menulis dan menghitung tetapi dengan cara yang menyenangkan melalui permainan dan nyanyian. Program-program TK Al-Qur'an Wahdatul Ummah dalam mempersiapkan anak ke jenjang Sekolah Formal sudah cukup efektif dan berhasil dengan baik.

\section{Keyword: Nilai Unggul, Sekolah Formal}

\section{A. PENDAHULUAN}

Pendidikan merupakan suatu unsur yang tidak dapat dipisahkan dari diri manusia. Mulai dari kandungan sampai beranjak dewasa kemudian tua. Manusia mengalami proses pendidikan yang didapat dari orang tua, masyarakat maupun lingkungannya. Life long education yang artinya "pendidikan sepanjang hayat," menjelaskan bahwa pendidikan telah menjadi kebutuhan pokok bagi manusia di sepanjang rentang kehidupan.

Masa anak-anak atau masa prasekolah merupakan masa-masa paling membahagiakan dari seluruh rentetan masa kehidupan. Anak-anak mulai bermain dengan imajinasi dan khayalannya dengan tidak takut melakukan apa saja sesuai dengan khayalannya itu. Hal ini perlu dijaga agar berjalan sebagaimana adanya agar menemukan tempat yang nyaman dan aman untuk berkembang.

Salah satu kebijakan pemerintah di sektor pendidikan guna mendukung pendidikan sepanjang hayat sebagai wadah berkembangnya potensi anak adalah diakuinya Pendidikan Anak Usia Dini selanjutnya disingkat PAUD. Dalam Undang-Undang No. 20 tahun 2003 tentang Sistem Pendidikan Nasional dalam pasal 1 ayat (14) disebutkan bahwa: Pendidikan Anak Usia Dini adalah suatu upaya pembinaan yang ditujukan kepada anak sejak lahir sampai dengan usia 6 tahun melalui pemberian rangsangan pendidikan untuk 
membantu pertumbuhan dan perkembangan jasmani dan rohani agar anak memiliki kesiapan dalam memasuki pendidikan lebih lanjut. ${ }^{1}$

PAUD adalah pendidikan yang cukup penting dan bahkan menjadi landasan kuat untuk mewujudkan generasi yang cerdas dan kuat. PAUD merupakan salah satu bentuk penyelenggaraan pendidikan yang menitikberatkan pada peletakan dasar ke arah pertumbuhan dan perkembangan fisik (koordinasi motorik halus dan kasar), kecerdasan (daya pikir, daya cipta, kecerdasan emosi, kecerdasan spiritual), sosio emosional (sikap dan perilaku serta agama) bahasa dan komunikasi, sesuai dengan keunikan dan tahap-tahap perkembangan yang dilalui oleh anak usia dini. Para ahli menemukan bahwa perkembangan otak manusia mencapai kapasitas 50\% pada masa anak usia dini. Para ahli menyebut usia dini sebagai usia emas atau golden age. ${ }^{2}$

PAUD berfungsi membina, menumbuhkan dan mengembangkan seluruh potensi anak usia dini secara optimal sehingga terbentuk perilaku dan kemampuan dasar sesuai dengan tahap perkembangannya. Agar memiliki kesiapan untuk memasuki pendidikan selanjutnya dalam rangka mencapai tujuan Pendidikan Nasional bahwa "Pendidikan nasional berfungsi mengembangkan kemampuan dan membentuk watak serta peradaban bangsa yang bermartabat dalam rangka mencerdaskan kehidupan bangsa bertujuan untuk berkembangnya potensi peserta didik agar menjadi manusia yang beriman dan bertaqwa kepada Tuhan yang Maha Esa, berakhlak mulia, sehat, berilmu, cakap, kreatif, mandiri, dan menjadi warga negara yang demokratis serta bertanggung jawab ".3

Berdasar uraian di atas tampak jelas pentingnya mengapa mendidik anak itu dimulai sejak dini, karena perkembangan jiwa anak telah mulai tumbuh sejak kecil, sesuai dengan fitrahnya. Hal ini sesuai dengan sabda Rasulullah SAW :

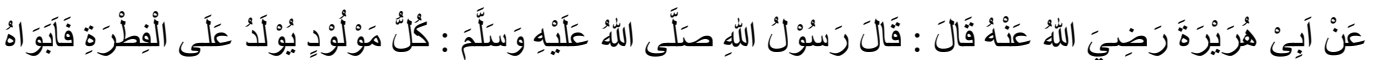

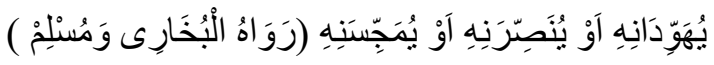

\footnotetext{
${ }^{1}$ Ali Aksun Widjaya, Undang-undang Republik Indonesia No. 20 Tahun 2003 tentang Sistem Pendidikan Nasional, Semarang: CV Duta Nusindo, 2003, hal. 6

${ }^{2}$ Putu Eka Wilantara, Peran Mutu Layanan PAUD Non Formal dalam mendukung anak jalanan menuntaskan wajib Belajar dalam http://edu-articles.com (diakses 22 juni 2019)

${ }^{3}$ Loc.Cit.
} 
Dari Abu Hurairah R.A, Ia berkata: Rasulullah SAW bersabda : "Setiap anak dilahirkan dalam keadaan Fitrah, ayah dan ibunyalah yang menjadikan Yahudi, Nasrani, atau Majusi." (HR. Bukhori dan Muslim). ${ }^{4}$

Dalam perspektif psikologi bayi lahir diibaratkan kertas putih yang belum mempunyai cacat atau coretan apapun. Baik buruknya kertas tersebut tergantung dari orang atau lingkungan yang ada disekitarnya. Jadi dapat dikatakan seorang bayi yang baru lahir sampai nanti menjadi dewasa, sikap, tingkah laku dan wataknya akan ditentukan oleh orang terdekat dan lingkungannya. Hal yang paling penting dalam membentuk awal adalah di lingkungan terdekat, yaitu keluarga. Jadi sifat yang dimiliki oleh anak tidak jauh berbeda dengan orang tua. Seperti pepatah dalam bahasa Inggris Like father like son; like mother like daughter, dalam bahasa Indonesia dapat diartikan "buah yang jatuh akan berada tidak jauh dari pohonnya". Mulai dari ibu sampai anggota keluarga lainnya dan seterusnya hingga pada masyarakat yang lebih luas. Jadi sedini mungkin anak sudah dan perlu mengalami proses belajar. Utamanya proses belajar yang berasal dari keluarga (informal), tetapi tak kalah penting anak pun memerlukan pembelajaran di tempat bersosialisasi formal yaitu melalui pendidikan pra sekolah.

Motivasi umum yang mendorong orang tua memasukkan anak mereka ke lembaga pendidikan pra sekolah adalah karena perkembangan kesadaran orang tua dalam pendidikan. Motivasi lain yang mendorong orang tua untuk menyekolahkan anak ke lembaga pendidikan pra sekolah adalah karena pendidikan pra sekolah memiliki manfaat yang tidak sedikit, salah satunya adalah memberikan kesempatan kepada anak-anak untuk memenuhi kebutuhan jasmani dan rohani serta mengembangkan bakat-bakatnya secara optimal. Selain itu juga memberikan bimbingan yang seksama agar anak-anak memiliki sifat-sifat, nilai-nilai dan kebiasaan yang berlaku dalam masyarakat masyarakat yang dinamis, yang secara langsung akan membawa dampak pada perkembangan anak.

Dewasa ini banyak bermunculan lembaga-lembaga pendidikan prasekolah, baik yang bersifat formal maupun informal, dengan berbagai macam

${ }^{4}$ Abi Al Husain Muslim Ibnu Al Hajjaj, Shahih Muslim, Juz 2 “ Kitab Qadar” Haits nomor 22 ( Beirut: Dar Al Kutub Al-ilmiah,tt), h. 556 
program unggulan yang ditawarkan. Hal ini merupakan satu hal yang menggembirakan, karena salah satu di antara sejumlah keuntungan pendidikan prasekolah adalah bahwa pusat pendidikan prasekolah tersebut memberikan pengalaman sosial di bawah bimbingan para guru yang terlatih yang membantu mengembangkan hubungan yang menyenangkan antar-personal. Hal ini akan sangat membantu perkembangan sosialisasi anak dalam mempelajari perilaku mana yang diterima dan ditolak secara sosial, sehingga anak lebih siap berinteraksi dengan lingkungan sosial yang lebih besar dari lingkungan keluarganya di rumah. Orang tua saat ini pun lebih cerdas yaitu memiliki kecenderungan memilih sekolah yang lebih banyak mengakses nilai-nilai agama untuk anak mereka. Seperti di kota Metro salah satu preschool yang banyak di minati yaitu Taman Kanak-kanak Islam Terpadu yang selanjutnya di sebut TKIT

Wahdatul Ummah di Kota Metro sebagai contohnya merupakan TKIT yang tepatnya di kelurahan Yosodadi kecamatan Metro Timur merupakam lembaga TK Islam Terpadu belakangan ini begitu meroket popularitasnya dikalangan masyarakat. Harapan dari orang tua tak lain dan tak bukan adalah supaya dapat tertanam nilai-nilai agama sedini mungkin, sehingga anak sudah memiliki dasar agama yang kuat untuk menanggulangi dampak dari perkembangan masyarakat saat ini. TKIT merupakan suatu lembaga yang menjalankan berbagai program yang telah diprogramkan oleh Islam Terpadu itu sendiri. Islam Terpadu itu merupakan suatu organisasi yang belakangan ini mulai baik namanya. Islam Terpadu yang tergabung dalam organisasi Jaringan Islam Terpadu menyediakan kurikulum yang sangatlah baik dan mumpuni untuk segi ke-Islaman. maka dari itu, diberi nama dengan Islam Terpadu. Artinya, secara umum yaitu memadukan nilai-nilai keIslaman dalam lingkungan lembaga sekolah. Berdasarkan pemikiran dan pernyataan tersebut, penulis memandang bahwa program PAUD merupakan hal penting guna mempersiapkan anak ke jenjang Sekolah formal. 


\section{B. METODE PENELITIAN}

Ditinjau dari permasalahan yang dikaji oleh penulis, maka dari itu metode penelitian yang penulis gunakan di sini menggunakan jenis penelitian pustaka dengan pendekatan kualitatif. ${ }^{5}$ Oleh sebab itu literatur utama yang di kaji dalam penelitian ini adalah buku serta jurnal-jurnal yang berkaitan dengan nilai unggul yang terdapat dalam pendidikan anak rasekolah, sebagai penelitian kepustakaan, maka metode pengumpulan data yang dipergunakan adalah metode dokumentasi, yaitu data tentang variabel yang berupa buku, jurnal dan lain-lain. Sedangkan teknik analisis yang dipilih adalah deskriptif analisis.

\section{PEMBAHASAN DAN HASIL PENELITIAN \\ 1. PROGRAM PAUD DI TKIT WAHDATUL UMMAH}

Visi TKIT Wahdatul Ummah adalah: menjadi lembaga pendidikan yang aman, mencintai lingkungan dan menyenangkan bagi anak usia dini di Kota Metro dalam mempersiapkan generasi Robani. Misinya: 1). Meletakkan dasar keimanan kepada Allah, 2) Melatih dan membiasakan anak beribadah dengan benar, 3) Membiasakan menghafal Al-Qur'an juz 30, hadits-hadits pendek dan do'a sehari-hari. 4) Menciptakan lingkungan pembelajaran yang menyenangkan dan interaktif, 5) Mewujudkan suasana kasih sayang sesama warga sekolah, 6) Menyediakan alat/sarana permainan yang edukatif, 7) Mengenalkan dasardasar/konsep calistung.

Dalam program kegiatan belajar mengajar TKIT Wahdatul Ummah merupakan satu kesatuan program kegiatan belajar yang utuh. Program kegiatan ini berisi bahan-bahan pembelajaran yang di susun menurut pendidikan tematik. Pendidikan tematik adalah organisasi dari kurikulum dan pengalaman belajar melalui pemilihan topik. Pemilihan topik harus disesuaikan dengan kondisi anak didik untuk mengembangkan keterampilan dan pengetahuan yang sesuai dengan tujuan kegiatan.

Berdasarkan wawancara langsung dengan kepala sekolah dan beberapa guru di TKIT Wahdatul Ummah didapatkan informasi bahwa materi bidang

${ }^{5}$ Lexy J Moleong, Metode Penelitian Kualitatif (Bandung: Remaja Rosdakarya, 1990), 2. 
pengembangan agama Islam di TKIT Wahdatul Ummah termasuk dalam kategori tinggi misalnya materi pendidikan aqidah. Dari segi perkembangan afektif anak didik belum siap untuk menerima materi itu walaupun daya pikir anak didik pada saat ini harus di latih dan di kembangkan. Materi pendidikan akhlak sudah diajarkan pada anak didik karena sejak dini anak di latih untuk menghormati yang lebih tua serta menyayangi yang lebih muda, memelihara keadaan alam sekitar agar nantinya anak mampu menjadi orang yang baik dan berakhlakul karimah sesuai dengan tujuan yang ada di lembaga tersebut, sehingga mampu membawa dirinya ke tengah- tengah masyarakat.

Materi pendidikan ibadah dan amal sholeh seperti belajar praktik wudhu, hafalan bacaan shalat sesuai sunnah Rasulullah SAW, praktik shalat, belajar do'a-do'a harian dan menghafal surat-surat pendek khususnya Al-Qur'an juz 30 sangat menarik perhatian anak didik. Terbukti banyak anak didik yang sudah hafal berbagai do, bacaan shalat dan surat-surat pendek.

Dari segi perkembangan psikomotorik anak kurang. karena pada taman kanak-kanak bukan sekolah, TK merupakan tempat bermain seraya belajar. Untuk itu dalam proses penyampaian materi tentang doa - doa serta surat surat pendek guru tidak menyuruh anak didik untuk menulis melainkan menghafal doa-doa tersebut. Di TK tidak di berikan pelajaran membaca dan menulis. Kegiatan-kegiatan tersebut di lakukan oleh guru dengan suasana yang menyenangkan misalnya: bernyanyi, bermain, mengucap syair dan lain- lain.

Kebanyakan TK maupun TPQ hanya mengajarkan kegiatan membaca saja hal ini kurang ideal karena untuk melanjutkan ke jenjang yang lebih tinggi mereka harus bisa membaca dan menulis agar kelak mereka bisa mengikuti pelajaran dengan baik sebagaimana mestinya. Oleh karena itu secara umum menunjukkan bahwa Program PAUD yang ada di Wahdatul Ummah antara lain; Tempat penitipan anak, play group, TK Al-Qur'an, TPA, pendidikan ibu dan anak (parenting). Upaya TK Al-Qur'an dalam mempersiapkan anak ke jenjang Sekolah Formal antara lain; dengan mempersiapkan personal, sosial dan akademik anak. Programnya di antaranya yaitu; pemeriksaan fisik, bermain, bercerita, bernyanyi, outbound dan pembelajaran melalui sentra, gambar, pendalaman 
materi pembelajaran yang melingkupi pengembangan aspek; agama dan moral, fisik, bahasa, kognitif, sosial emosional, seni dan keterampilan hidup, pengenalan Bahasa Inggris dan Bahasa Arab dasar, Karya wisata, Informasi Pemantaan oleh Guru dan Orang tua, mengikuti kegiatan Hari Besar Islam dan Nasional.

\section{UPAYA TKIT WAHDTUL UMMAH MEMPERSIAPKAN ANAK MEMASUKI SEKOLAH FORMAL}

\section{a) Pendidik / Guru}

Dalam sebuah kegiatan belajar mengajar guru merupakan aspek terpenting. Untuk mendidik anak agar menjadi orang yang baik dan selalu taat beribadah di perlukan guru yang professional. Sedangkan kegiatan guru yang penulis amati di TKIT Wahdatul Ummah adalah :

a. Dalam proses pembelajaran guru menjadi teman yang baik dan bukan menjadi guru yang di takuti tapi di hormati

b. Guru menjalin hubungan dengan wali murid (berkomunikasi) untuk mengetahui perkembangan anak didik setelah di luar kelas

c. Guru disini bertugas sebagai pengamat yang melakukan interaksi antar anak maupun interaksi anak dengan benda-benda sekitar

d. Peran guru dalam proses penanaman nilai-nilai agama islam sebagai pengamat, melakukan elaborasi, sebagai model, melakukan evaluasi dan melaksanakan perencanaan

Sebagaimana telah di uraikan bahwa dalam ajaran agama Islam guru atau pendidik mendapatkan penghormatan dan kedudukan yang amat tinggi. Kedudukan yang amat tinggi ini sangat logis di berikan kepadanya karena di lihat dari jasanya yang demikian besar dalam membimbing, mengarahkan, memberikan pengetahuan, membentuk akhlak dan menyiapkan anak didik agar siap menghadapi masa depan dengan penuh keyakinan dan percaya diri.

Untuk dapat melaksanakan tugas tersebut, di samping seorang guru harus menguasai pengetahuan yang akan di ajarkannya kepada murid,harus memiliki sifat-sifat tertentu yang dengan sifat-sifat ini di harapkan apa yang di berikan 
oleh guru kepada para muridnya dapat di dengar dan di patuhi, tingkah lakunya dapat di tiru dan di teladani dengan baik.

Diantara sifat-sifat yang harus di miliki oleh seorang guru antara lain :

1) Seorang guru harus memiliki sifat zuhud yaitu tidak mengutamakan untuk mendapatkan materi dalam tugasnya, melainkan mengharapkan keridhoan Allah semata.

2) Seorang guru harus memiliki jiwa yang bersih dari sifat akhlak yang buruk

3) Seorang guru harus ikhlas dalam melaksanakan tugasnya dan bersifat pemaaf

4) Seorang guru harus mengetahui bakat,tabiat, dan watak muridmuridnya.

Di sinilah pentingnya seorang pendidik bagi murid, karena dalam sebuah keluarga belum tentu mereka mendapat pendidikan yang di ajarkan di sekolah mungkin di karenakan kesibukan dari orang tuanya sehingga tidak bisa memberi perhatian khusus. Kadaan guru di TKIT Wahdatul Ummah saat ini terdiri dari 17 guru, yang tersebar di kampus 1 dan 2. Kampus 1 beralamatkan di Jl. Ikan Koi NO. 5 Yosorejo kec Metro timur, sementara TKIT Wahdatul Ummah kampus 2 di 15 B Timur.

\section{b. Alat / Sarana}

Alat atau sarana yang di gunakan dalam penanaman nilai agama islam di TKIT Wahdatul Ummah Alat atau sarana yang di gunakan sudah cukup untuk mendukung proses pembelajaran, dalam hal ini adalah penanaman nilai-nilai agama islam. Alat atau sarana yang di gunakan sudah cukup memenuhi perkembangan anak didik dari segi fisik, perkembangan sosial, perkembangan intelektual, perkembangan kreativitas dan perkembangan bahasa. Meskipun hal tersebut sudah memadai bagi anak-anak alangkah baiknya pendidikan anak di TK perlu di lengkapi dengan media pembelajaran yang memadai seperti tape recorder, kaset-kaset lagu islami, TV, kaset video untuk praktek sholat, buku-buku bacaan atau majalah anak-anak. Dengan adanya media 
itu di harapkan agar komunikasi dan interaksi guru murid tidak bersifat monoton,tetapi lebih bervariasi disamping itu anak akan lebih betah / kerasan belajar di TK. Namun demikian, seperangkat media tersebut tidak banyak di miliki oleh sebagian TK/TPQ karena keterbatasan dana.

\section{c. Pendekatan}

Dalam proses belajar mengajar sebuah pendekatan mempunyai arti yang penting dalam upaya mencapai tujuan pendidikan. Pendekatan yang dimaksud di sini adalah bagaimana mewujudkan kebersamaan siswa dalam lingkungannya, baik di sekolah maupun di lingkungan masyarakat. Seharusnya pola pendekatan ini di tekankan pada aspek tingkah laku di mana guru hendaklah dapat menanamkan rasa kebersamaan dan siswa dapat menyesuaikan diri baik dalam individu maupun sosialnya.

Dengan berdasarkan pendekatan ini, materi yang di persiapkan untuk di sampaikan kepada anak didik adalah materi yang sesuai dengan kebutuhan anak didik dalam kehidupan bermasyarakat. Karena harus di sadari sepenuhnya, bahwa materi pelajaran yang di sampaikan kepada anak. didik tidak hanya sekedar untuk memajukan aspek kognitifnya saja tetapi juga untuk kelangsungan kehidupannya di masa-masa mendatang.

Dengan adanya pendekatan-pendekatan tersebut hendaknya setiap sekolah di tanah air dapat menjembatani keinginan-keinginan tersebut di atas, oleh karena itu di butuhkan metode mengajar yang serasi, seimbang, dan progresif guna mencapai tujuan yang di maksud. Dan setiap guru atau pendidik harus selalu berusha untuk "membakar', semangat anak didiknya dalam melaksanakan ajaran-ajaran agama yang sesuai dengan tuntunan Alqur'an. Memberikan sentuhan rohani kepada anak didik diyakini sangat besar kontribusinya dalam memicu dan memacu semangat mereka dalam beribadah dan menuntut ilmu.

Pendekatan dalam pendidikan islam adalah sebuah asumsi terhadap hakikat pendidikan islam. Setiap pendekatan yang di gunakan akan memakai metode yang berbeda antar satu pendekatan dengan pendekatan yang 
lainnya, oleh karena metode selalu terkait dengan pendekatan, sementara pendekatan merujuk pada tujuan.

\section{d. Metode}

Metode sangat penting di gunakan dalam rangka memberikan pengetahuan tentang agama kepada anak didik. Jika tidak adanya sebuah metode anak tersebut tidak tertarik kepada apa yang kita sampaikan. Metode yang di pakai untuk menanamkan nilai-nilai agama islam banyak sekali, tapi yang paling efektif yaitu metode bermain. Bermain merupakan kegiatan yang memungkinkan anak memperoleh keberhasilan serta membantu perkembangan psikomotorik sang anak. Sedangkan metode Tanya jawab memang membantu bahasa anak tapi bagi anak kurang aktif di dalam kelas. Metode ini kurang ideal di karenakan anak bisa main sendiri, melamun atau mungkin mengantuk.

Selain metode di atas, juga ada metode karyawisata, metode ini kurang efektif untuk di gunakan . tapi membuat anak menjadi senang, dari segi waktu tidak efektif dari segi materi juga membutuhkan biaya yang tidak sedikit. Untuk itu metode ini dipakai sekali dalam satu tahun.Metode yang dipakai dalam penanaman nilai agama islam sangat bervariasi agar anak didik tidak cepat jenuh. Metode hukuman belum dapat di gunakan di TKIT Wahdatul Ummah, karena bila di gunakan tidak ideal bagi anak didik dan menjadikan anak bosan dan takut untuk bersekolah nantinya. Pada dasarnya semua metode itu baik tapi yang paling baik adalh metode yang sesuai dengan pendidik, anak didik serta bahan pelajaran yang telah di sesuaikan berdasarkan tujuan yang ada.

\section{e. Evaluasi}

Dari Penanaman Nilai-nilai Agama Islam di TKIT Wahdatul Ummah Evaluasi dalam pendidikan islam merupakan cara atau tehnik penilaian terhadap tingkah laku peserta didik berdasarkan standar perhitungan yang bersifat komprehensif dari seluruh aspek-aspek kehidupan mental-psikologis dan spiritual-religius peserta didik karena sosok pribadi yang di inginkan oleh 
pendidikan islam bukan hanya pribadi yang bersikap religius, tetapi juga memiliki ilmu dan berketerampilan yang sanggup beramal dan berbakti kepada Allah dan masyarakat. karena evaluasi bertujuan mengumpulkan informasi yang dapat di pergunakan sebagai dasar untuk mengadakan pengecekan yang sistematis terhadap hasil pendidikan yang telah di capai untuk kemudian di bandingkan dengan tujuan yang telah di tetapkan sebelumnya.

Evaluasi ini di lakukan untuk mengetahui sejauh mana proses pembelajaran dan perkembangan anak didik yang ada di TKIT Wahdatul Ummah selama satu semester dengan didasarkan atas selang waktu dan berkali-kali dengan suatu tujuan tertentu. Pencatatan perkembangan anak (evaluasi) di laporkan kepada orang tuanya setiap akhir semester. Pencatatan perkembangan di lakukan berdasarkan hasil penelitian guru dan pemberian tugas. Adapun tujuan dan fungsi di adakan evaluasi adalah sebagai berikut

a. Untuk memberikan umpan balik (feed back) kepada guru sebagai dasar untuk memperbaiki serta mengamati tingkah laku perkembangan anak didik dalam proses pembelajaran.

b. Untuk menentukan mampu dan tidaknya masing-masing anak didik dalam menerima materi sehingga mampu di amalkan dalam kehidupan sehari-hari

c. Untuk menempatkan anak didik dalam situasi belajar mengajar yang tepat, sesuai dengan tingkat kemampuan perkembangan yang di miliki anak didik

d. Untuk mengenal latar belakang (psikologi, fisik dan lingkungan) murid yang megalami kesulitan belajar yang hasilnya dapat di gunakan sebagai dasar dalam memecahkan kesulitan-kesulitan tersebut.

Seharusnya evaluasi tidak hanya di lakukan satu semester saja akan tetapi harus di lakukan setiap saat dan setiap waktu pada saat membuka pelajaran, menyajikan pelajaran apalagi menutup pelajaran. Dengan evaluasi secara kontiniu ini perkembangaa anak didik dapat terkontrol dengan baik dan evaluasi hendaknya di lakukukan untuk semua aspek sasaran pendidikan 
yaitu aspek kognitif, afektif dan psikomotorik.

\section{PROGRAM UNGGULAN DI TKIT WAHDATUL UMMAH}

Program-program di TKIT Wahdatul Ummah semuanya program unggulan hanya saaja kemitraan dengan orang tua benar-benar menjadi focus TKIT dalam mempersiapkan anak memasuki jenjang sekolah formal. Edukasi(Parenting) rutin dilakukan dengan tujuan orang tua dan guru dapat bersinergi mejadikan anak benar-benar siap memasuki jenjang sekolah formal seperti pada materi pelajaran yang akan dihadapi di SD berkaitan dengan kemampuan dasar anak seperti calistung ( kognitif) . Guru, orangtua dapat menstimulasi anak untuk mulai mengenal angka, mengenal huruf (huruf capital dan huruf kecil), belajar menggunakan pensil yang benar, belajar menggambar sesuatu yang bermakna seperti matahari, bunga, orang, dllnya, atau melakukan aktivitas lainnya yang juga mampu meningkatkan daya ingat dan daya konsentrasi anak. Kegiatan membaca buku, membatasi aktivitas menonton dan menggantinya dengan aktivitas/permainan terkait literasi (seperti bermain peran sekolah-sekolahan, atau menulis huruf), atau kegiatan bernyanyi serta membaca sajak dapat menjadi alternatif kegiatan yang dilakukan orangtua untuk menstimulasi perkembangan bahasa anak. Namun program paling unggulan yang ditawarkan TK Al-Qur'an Wahdatul Ummah dalam mempersiapkan anak memasuki jenjang Sekolah Formal yaitu melalui menghafal baik bacaan do, shalat, suratsurat pendek dan mengenalkan angka huruf, membaca, menulis dan menghitung tetapi dengan edukasi yang menyenangkan melalui permainan dan nyanyian.

\section{PENUTUP}

Kesiapan sekolah merupakan hal penting yang perlu dimiliki anak sebelum ia masuk ke Sekolah Dasar (SD). Kesiapan sekolah dapat membantu anak untuk beradaptasi pada masa transisi, karena pendidikan di TK/PAUD sangat berbeda dengan pendidikan di SD. Berdasarkan beberapa penelitian diketahui bahwa anak yang telah memiliki kesiapan sekolah akan mampu mengikuti 
pembelajaran, mampu menyelesaikan tugas-tugasnya, dan mencapai prestasi akademik yang lebih baik jika dibandingkan anak yang belum memiliki kesiapan sekolah, serta memiliki konsep diri dan minat belajar yang positif. Melalui tinjauan lapangan diketahui bahwa Program PAUD yang ada di Wahdatul Ummah antara lain; Tempat penitipan anak, play group, TK AlQur'an, TPA, pendidikan ibu dan anak (parenting). Upaya TK Al-Qur'an dalam mempersiapkan anak ke jenjang Sekolah Formal antara lain; dengan mempersiapkan personal, sosial dan akademik anak. Programnya di antaranya yaitu; pemeriksaan fisik, bermain, bercerita, bernyanyi, outbound dan pembelajaran melalui sentra, gambar, pendalaman materi pembelajaran yang melingkupi pengembangan aspek; agama dan moral, fisik, bahasa, kognitif, sosial emosional, seni dan keterampilan hidup, pengenalan Bahasa Inggris dan Bahasa Arab dasar, Karya wisata, Informasi Pemantauan oleh Guru dan Orang tua, mengikuti kegiatan Hari Besar Islam dan Nasional. Selain itu TKIT Wahdatul UMmah juga mempertimbangkan aspek guru, materi, sarana prasarana, metode dan evaluasi. Program unggulan yang ditawarkan TK Al-Qur'an Wahdatul Ummah dalam mempersiapkan anak memasuki jenjang Sekolah Formal yaitu melalui menghafal baik bacaan do, shalat, surat-surat pendek dan mengenalkan angka huruf, membaca, menulis dan menghitung tetapi dengan cara yang menyenangkan melalui permainan dan nyanyian.

\section{E. DAFTAR PUSTAKA}

Abi Al Husain Muslim Ibnu Al Hajjaj, Shahih Muslim, Juz 2 “ Kitab Qadar” Haits nomor 22 Beirut: Dar Al Kutub Al-ilmiah,tt

Ali Nugraha dan Neny Ratnawati, Kiat Merangsang Kecerdasan Anak, Jakarta: Puspa Swara, 2004

Ali Aksun Widjaya, Undang-undang Republik Indonesia No. 20 Tahun 2003 tentang Sistem Pendidikan Nasional, Semarang: CV Duta Nusindo, 2003, hal. 6

Dewi Sartika dkk, Prosiding SNaPP2011: Sosial,Ekonomi, dan Humaniora, Prosiding SNapp 2011,ISSN 20189-3590

Evi Deviliana, Mempersiapkan Anak memasuki Sekolah Dasar, JDP , Volume 10, Nomor 2, Juli 2017

H.M Arifin, Kapita Selekta Pendidikan Islam dan Umum, Jakarta: Bumi Aksara, 1995 
Jessica S. Hagan, Mendidik Anak Memasuki Usia Prasekolah, Jakarta: Prestasi Pustakarya, 2006

Peraturan Pemerintah RI No. 27 Tahun1990 tentang Pendidikan Prasekolah, dalam www.bphn.go.id90pp027 pdf.

Putu Eka Wilantara, Peran Mutu Layanan PAUD Non Formal dalam mendukung anak jalanan menuntaskan wajib Belajar dalam http://edu-articles.com (diakses 22 juni 2019)

Sri Harini dan Aba Firdaus Al Halwani, Mendidik Anak Sejak Dini, Yogyakarta: Kreasi Wacana, 2003

Soemarti Patmonodewo, Pendidikan Anak Prasekolah, Jakarta: Rineka Cipta, 2000

UU Sisdiknas, Undang-undang Replublik Indonesia no. 20 Tahun 2003

Tentang Sistem Pendidikan Nasional, Jakarta: Sinar Grafika, 2003 
Volume 1 No 1 2019, J-Sanak_Jurnal Kajian Anak | 94 